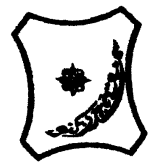

Bayero Journal of Pure and Applied Sciences, 5(1): 48 - 56

Received: September 2011

Accepted: March 2012

ISSN $2006-6996$

\title{
FOLIAR EPIDERMAL CHARACTERS OF SOME STERCULIACEAE SPECIES IN NIGERIA
}

*Aworinde, D.O., Ogundairo, B.O., Osuntoyinbo, K.F. and Olanloye, O.A.

Department of Biological Sciences, University of Agriculture, Abeokuta, Ogun State, Nigeria

*Correspondence author: davidaworinde@yahoo.com

\begin{abstract}
Foliar epidermal studies were conducted on ten species in the family Sterculiaceae in search of stable taxonomic characters that could be employed in order contribute to their classification and identification. In spite of the remarkable morphological differences, the results indicated that the species are relatively uniform in their quantitative macromorphological characters except for the leaf shape and base which varied from elliptic, lanceolate to palmate and leaf base from cordate, obtuse to cunneate. The epidermal characters such as number of cells, anticlinal wall pattern, cell wall thickness and the stomata size varied among the species. The epidermal cells varied from polygonal to irregular while the anticlinal walls varied from straight to straight|curve and slightly curved. All the species except Cola nitida (Vent) Schott, Malachanta alnifolia (Bak) Pierre, Mansonia altissima (A.Chev) R.Capuron, Theobroma cacao Linn and Waltheria indica Linn are amphistomatic. Stomata types included anisocytic in T. cacao, laterocytic in C. hispida, anomocytic in C. millenni Schum, Staurocytic in C. nitida and paracytic in W. indica, M. altissima and Malacantha alnifolia. Keywords: Foliar epidermis, Nigeria, Sterculiaceae.
\end{abstract}

\section{INTRODUCTION}

The family name Sterculiaceae was based on the genus Sterculia. The family is made up of trees, shrubs, and herbs comprising about 70 genera, totaling around 1500 species which are found majorly in the tropics (Burkill, 1985). They are further characterized by the presence of stellate hairs. The leaves are simple or infrequently palmately lobed or compound. They have stipulate leaves which are caducous. The most famous species of the family are Theobroma cacao and Cola species. According to Motamayor and Lanaud (2002) Theobroma cacao is an indigene of South America and is commercially exploited for its seed output that is mainly destined for manufacturing chocolate products. Cola species, a tropical African genus of the family comprises 122 species which are mostly evergreen, small or moderately sized tree and is widely cultivated in tropical countries especially in Nigeria because of its economic importance. The species considered in this study are Theobroma cacao, Cola hispida Brenan \& Keay, C. millenni, C. nitida, Triplochyton scleroxylon, Malanchata alnifolia, Mansonia altissima, Waltheria indica, Pterigota marcocarpa K.Schum and Kleinhovia hospita L. All the studied species are trees except for Waltheria indica which is a shrub. Various characters have been used in describing and delimiting species in the family Sterculiaceae, but not much attention has been drawn to the leaf epidermal characters, it is therefore imperative to attempt a search for epidermal characters that may be of taxonomic importance. The main objective of this work was to study the leaf epidermis of some species of Sterculiaceae in Nigeria in search of useful and stable taxonomic characters that can assist in identifying and enable a better understanding of the variations among the species even in their fragmentary state.

\section{MATERIALS AND METHODS}

Seven plant genera in the family Sterculiaceae were selected for the study. Fresh samples used for these investigations were collected from UIH (abbreviation according to Holmgren and Keuken, 1974), Agodi Botanical garden and some field collections were also made. Measurement of parameters for morphological data followed Isawunmi (1989) and observation of quantitative characters was made in situ. Specimens were prepared for photomicrography as described by Aworinde and Ogundairo (2009).

Stomata index (SI) was calculated using the formula of Salisbury (1972) as modified by Hussin et al., (2000).

$$
\frac{\mathrm{S}}{\mathrm{S}+\mathrm{E}} \quad \mathrm{X} \quad 100
$$

Where $S$ denotes number of stomata per unit area and $E$ number of epidermal cells of the same area. Measurement of the epidermal cell width was taken at the widest point on each cell.

\section{RESULTS}

Parameters of morphological and anatomical importance are presented in Tables 1-5 while Figures $A$ - $T$ are the images from the photomicrographic study.

\section{Macromorphological characters}

Leaves in Sterculiaceae family are simple, having opposite or whorled arrangement and mostly entire and stipulate. The leaf shapes varied from elliptic, lanceolate to palmate but rarely obovate (Table 3 ). The leaves are mostly glabrous in all except Cola hispida, Malachanta alnifolia, Mansonia altissima and Waltheria indica. 
The apices are mostly acuminate with the exception of Waltheria indica which is acute. The bases are mostly cordate and the leaf sizes show considerable variation within the family with the largest in Pterigota marcocarpa having $38 \mathrm{~cm}$ and the smallest $C$. nitida having $18 \mathrm{~cm}$ respectively. The lowest leaf length $/$ width ratio ranges from 1:1 to 2:1 (Table 3).

\section{Micromophological characters \\ Epidermal cells}

Leaf epidermal cells are irregular or more often polygonal. Anticlinal wall patterns are slightly curved to straight. Irregular cells exist more often on the abaxial surfaces than adaxial surfaces. The irregular cells are sometimes intermixed with polygonal cells in Kleinhovia hospita and Malanchata alnifolia. The polygonal and irregular epidermal cells possess straight/curved anticlinal walls but in few cases they have straight or slightly curved walls $T$. cacao, $M$ altissima, $K$. hospita and $M$. alnifolia (Fig. A, O, K and M) (Table 1 and 2). Variation also occurs in the number of epidermal cells on both the adaxial and abaxial surfaces. On the abaxial surface, $M$. alnifolia has the highest mean number of $218 \mu \mathrm{m}$ while $K$. hospita has the lowest mean of $49.1 \mu \mathrm{m}$. Also, on the adaxial surface $C$. milleni has the highest mean number of $363.4 \mu \mathrm{m}$ with $W$. indica having the lowest mean of 32.3 $\mu \mathrm{m}$ (Table 4).
The epidermal cell walls are thick ranging from $7.4 \mu \mathrm{m}$ in $P$. macrocarpa to $1.4 \mu \mathrm{m}$ in $M$. altissima on the abaxial surface. The cell wall thickness on the adaxial surface ranged from $1.8 \mu \mathrm{m}$ in $M$. alnifolia to $7.8 \mu \mathrm{m}$ in $P$. macrocarpa (Table 4). Abaxial epidermal cell walls are generally less thick than adaxial cell walls.

\section{Stomata}

The most common type of stomata in the family is paracytic as found in $P$. marcocarpa, $M$. altissima and $M$. alnifolia. In amphistomatic taxa the stomata are more frequent on the abaxial surfaces (Table 1 and 2). The mean stomata number varied from 10.2 in $K$. hospita to 242.8 in $T$. cacao on the abaxial surface with stomata index ranging from 14.5 to $60.6 \%$ in $P$. marcocarpa and C. nitida respectively. On the adaxial surface, the mean stomata number ranged from 6.4 in W. indica to 139 in $T$. scleroxylon with a stomata index of 2 to 29.8 in $C$. nitida and $M$. alnifolia respectively (Table 5 ). Generally, more stomata occur on the abaxial surface than the adaxial surface. Mean stomata length is in the range of 26 to $61.4 \mu \mathrm{m}$ in $T$. cacao and $C$. milleni respectively on the abaxial surface while it ranged from 30.4 to $64.5 \mu \mathrm{m}$ in T.cacao and $C$. nitida on the adaxial surface. Mean stomata width varies from $7.1 \mu \mathrm{m}$ in $P$. macrocarpa to $22.1 \mu \mathrm{m}$ in $C$. nitida on the abaxial surface and $12 \mu \mathrm{m}$ in $T$. cacao to $26.5 \mu \mathrm{m}$ in $C$. nitida on the adaxial surface (Table 5).

Table 1: Epidermal characters of some species of Sterculiaceae (Abaxial surfaces)

\begin{tabular}{lccccccccccc}
\hline TAXA & \multicolumn{10}{c}{ CHARACTER CODES } & \multicolumn{1}{c}{} \\
& 1 & 2 & 3 & 4 & 5 & 6 & 7 & 8 & 9 & 10 & 11 \\
\hline Theobroma cacao & + & - & + & - & - & + & - & - & - & - & - \\
Waltheria indica & + & - & - & + & - & + & - & - & - & - & - \\
Cola nitida & + & - & - & - & + & - & + & - & - & - & - \\
Cola millenni & + & - & - & + & - & - & - & - & - & - & + \\
Cola hispida & - & + & - & - & + & - & - & - & + & - & - \\
Mansonia altissima & + & - & + & - & - & - & - & + & - & - & - \\
Triplochyton scleroxylon & + & - & - & - & + & - & - & - & - & + & - \\
Kleinhovia hospita & - & + & + & - & - & + & - & - & - & - & - \\
Malanchata alnifolia & - & + & - & + & - & - & - & + & - & - & - \\
Pterigota marcocarpa & + & - & - & + & - & - & - & + & - & - & - \\
\hline
\end{tabular}

Legend to character codes: $1=$ polygonal cell shape, 2 = irregular cell shape, 3 slightly curved anticlinal wall pattern, $4=$ straight anticlinal wall pattern, $5=$ straight/curved anticlinal wall pattern $6=$ anisocytic stomata type, $7=$ staurocytic stomata type, $8=$ paracytic stomata type, $9=$ laterocytic stomata type, $10=$ absence of stomata, $11=$ anomocytic stomata type.

Table 2: Epidermal characters of some species of Sterculiaceae (Adaxial surfaces)

\begin{tabular}{lccccccccccc}
\hline TAXA & $\mathbf{1}$ & CHARACTER CODES & & & & & \\
& $\mathbf{1}$ & $\mathbf{2}$ & $\mathbf{3}$ & $\mathbf{4}$ & $\mathbf{5}$ & $\mathbf{6}$ & $\mathbf{7}$ & $\mathbf{8}$ & $\mathbf{9}$ & $\mathbf{1 0}$ & $\mathbf{1 1}$ \\
\hline Theobroma cacao & + & - & + & + & - & + & - & - & - & - & - \\
Waltheria indica & + & - & - & - & + & - & - & + & - & - & - \\
Cola nitida & + & - & - & - & + & - & + & - & - & - & - \\
Cola millenni & + & - & - & - & + & - & - & - & - & + & - \\
Cola hispida & - & + & - & - & + & - & - & - & - & + & - \\
Mansonia altissima & - & + & - & - & + & - & - & + & - & - & - \\
Triplochyton scleroxylon & + & - & - & + & - & - & - & - & - & - & + \\
Kleinhovia hospita & + & - & - & + & - & - & - & - & - & + & - \\
Malanchata alnifolia & + & - & - & - & + & - & - & + & - & - & - \\
Pterigota marcocarpa & + & - & - & + & - & - & - & - & - & + & - \\
\hline
\end{tabular}

Legend to character codes: $1=$ polygonal cell shape, $2=$ irregular cell shape, 3 slightly curved anticlinal wall pattern, $4=$ straight anticlinal wall pattern, $5=$ straight/curved anticlinal wall pattern $6=$ anisocytic stomata type, $7=$ staurocytic stomata type, $8=$ paracytic stomata type, $9=$ laterocytic stomata type, $10=$ absence of stomata, 11 = anomocytic stomata type. 
Table 3: Leaf morphological features of some species of Sterculiaceae (all quantitative characters min.(mean \pm s.e.)max)

\begin{tabular}{|c|c|c|c|c|c|c|c|c|c|}
\hline$\underset{\mathbb{2}}{\mathbb{R}}$ & $\frac{x}{\frac{x}{\sigma}}$ & 胥 & $\frac{8}{5}$ & ڤ్ర & 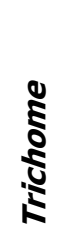 & $\begin{array}{l}\mathbf{S} \\
\text { ర్ } \\
\text { త్ }\end{array}$ & $\underset{\mathbf{s}}{\mathbf{s}}$ & \begin{tabular}{l}
5 \\
\multirow{2}{5}{} \\
$\frac{1}{0}$ \\
0 \\
0 \\
0 \\
0
\end{tabular} & 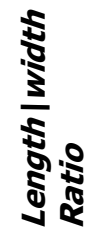 \\
\hline Cola hispida & Acuminate & Entire & Elliptic & Obtuse & ++ & $6.5(12.1 \pm 0.8) 15.6$ & $4.1(9.3 \pm 0.7) 12.0$ & $8.3(15.2 \pm 0.9) 18.2$ & $1: 1$ \\
\hline Cola millenni & Acuminate & Entire & Palmate & Cunneate & -- & $15.0(18.5 \pm 0.7) 21.0$ & $6.5(17.5 \pm 1.5) 22.5$ & $23.0(26.5 \pm 0.9) 31.0$ & $1: 1$ \\
\hline Cola nitida & Acuminate & Entire & Lanceolate & Obtuse & -- & $15.0(17.4 \pm 0.6) 21.0$ & $6.0(7.1 \pm 0.3) 9.0$ & $20.0(21.9 \pm 0.5) 25.0$ & $2: 1$ \\
\hline Kleinhovia hospita & Acuminate & Entire & Elliptic & Cordate & -- & $19.0(24.4 \pm 0.9) 29.0$ & $19.0(25.3 \pm 1.2) 29.0$ & $8.9(49.7 \pm 4.7) 61.0$ & $1: 1$ \\
\hline Malanchata alnifolia & Acuminate & Entire & Elliptic & Obtuse & ++ & $5.0(6.1 \pm 0.2) 7.2$ & $3.0(3.9 \pm 0.2) 4.9$ & $6.0(7.5 \pm 0.4) 9.5$ & $1: 1$ \\
\hline Mansonia altissima & Acuminate & Entire & Elliptic & Cordate & ++ & $15.0(23.4 \pm 1.6) 28.5$ & $12.0(18.4 \pm 1.2) 22.5$ & $18.0(29.6 \pm 2.3) 39.0$ & $2: 1$ \\
\hline Pterigota marcocarpa & Acuminate & Entire & Elliptic & Cordate & -- & $20.0(30.8 \pm 2.3) 41.0$ & $20.0(29.1 \pm 1.9) 36.9$ & $49.0(64.7 \pm 3.1) 79.0$ & $1: 1$ \\
\hline Theobroma cacao & Acuminate & Entire & Lanceolate & Obtuse & - & $30.0(32.1 \pm 0.5) 35.5$ & $9.5(10.8 \pm 0.3) 11.7$ & $31.0(33.6 \pm 0.6) 37.5$ & $2: 1$ \\
\hline Triplochyton scleroxylon & Acuminate & Entire & Palmate & Cunneate & - & $15.0(18.6 \pm 0.7) 21.5$ & $15.0(18.5 \pm 0.9) 22.5$ & $23.0(26.6 \pm 0.8) 31.0$ & $1: 1$ \\
\hline Waltheria indica & Acute & Crenate & Lanceolate & Cordate & ++ & $13.5(14.6 \pm 0.2) 15.5$ & $9.0(10.3 \pm 0.2) 11.7$ & $18.5(19.8 \pm 0.3) 21.0$ & $1: 1$ \\
\hline
\end{tabular}

denotes glabrous leaf

++ denotes pubescent leaf

Table 4: Variation in epidermal cell size and cell wall thickness of the studied taxa

\begin{tabular}{|c|c|c|c|c|}
\hline Taxa & $\begin{array}{l}\text { Number of cells } \\
\text { per ( } \mu \text { m) } \\
\text { (Abaxial) }\end{array}$ & $\begin{array}{c}\text { Number of cells } \\
\text { per }(\mu m) \\
\text { (Adaxial) }\end{array}$ & $\begin{array}{c}\text { Cell wall } \\
\text { Thickness }(\mu \mathrm{m}) \\
\text { (Abaxial) }\end{array}$ & $\begin{array}{l}\text { Cell wall } \\
\text { Thickness }(\mu \mathrm{m}) \\
\text { (Adaxial) }\end{array}$ \\
\hline Cola hispida & $59(93.4 \pm 10.7) 152$ & $150(187.7 \pm 6.4) 217$ & $2(4.9 \pm 0.5) 7$ & $5(7.1 \pm 0.5) 10$ \\
\hline Cola millenni & $90(110.4 \pm 4.8) 140$ & $299(363.4 \pm 15.6) 430$ & $3(4.1 \pm 0.2) 5$ & $4(5.5 \pm 0.3) 7$ \\
\hline Cola nitida & $136(205.4 \pm 14.1) 268$ & $48(102 \pm 11.2) 160$ & $5(6.9 \pm 0.4) 9$ & $5(6.5 \pm 0.3) 8$ \\
\hline Kleinhovia hospital & $37(49.1 \pm 2.4) 58$ & $159(177.6 \pm 3.9) 200$ & $2(3.3 \pm 0.4) 5$ & $1(2.3 \pm 0.3) 4$ \\
\hline Malanchata alnifolia & $188(218 \pm 8.2) 268$ & $72(97.2 \pm 5.1) 120$ & $1(1.8 \pm 0.3) 3$ & $1(1.5 \pm 0.2) 3$ \\
\hline Mansonia altissima & $72(97.2 \pm 5.1) 120$ & $188(213.2 \pm 6.1) 240$ & $1(1.4 \pm 0.2) 3$ & $1(2.2 \pm 0.5) 5$ \\
\hline Pterigota marcocarpa & $170(188.4 \pm 4.9) 210$ & $200(218.1 \pm 4.2) 240$ & $3(7.4 \pm 0.6) 10$ & $7(7.8 \pm 0.3) 9$ \\
\hline Thebroma cacao & $143(187.3 \pm 9.7) 230$ & $160(211.9 \pm 10.0) 260$ & $4(5.9 \pm 0.4) 8$ & $4(6.4 \pm 0.4) 8$ \\
\hline Triplochyton scleroxylon & $59(83.5 \pm 6.8) 139$ & $200(217.1 \pm 4.2) 239$ & $1(3 \pm 0.3) 5$ & $4(6.6 \pm 0.4) 8$ \\
\hline Waltheria indica & $80(98 \pm 4.4) 120$ & $12(32.3 \pm 3.2) 45$ & $1(1.7 \pm 0.2) 3$ & $1(1.6 \pm 0.2) 3$ \\
\hline
\end{tabular}


Table 5: Stomata character of the studied taxa [all measurement in $\mu \mathrm{m}(\min$ (mean $\pm \mathrm{s.e}) \mathrm{max})$ ].

\begin{tabular}{|c|c|c|c|c|c|c|c|c|}
\hline Taxa & $\begin{array}{l}\text { Stomata Density } \\
\text { per } \mu m \\
\text { (Abaxial) }\end{array}$ & $\begin{array}{c}\text { StomataDensity } \\
\text { per } \mu m \\
\text { (Adaxial) }\end{array}$ & $\begin{array}{c}\text { Stomata length } \\
\text { (Abaxial) }\end{array}$ & $\begin{array}{c}\text { Stomata length } \\
\text { (Adaxial) }\end{array}$ & $\begin{array}{c}\text { Stomata Width } \\
\text { (Abaxial) }\end{array}$ & $\begin{array}{c}\text { Stomata Width } \\
\text { (Adaxial) }\end{array}$ & $\begin{array}{c}S . I \% \\
(A b)\end{array}$ & $\begin{array}{c}S . I \\
\% \\
(A d)\end{array}$ \\
\hline Cola hispida & $15(20.4 \pm 1.9) 35$ & - & $50(58 \pm 1.9) 65$ & - & $10(18.7 \pm 1.3) 23$ & - & 60.6 & - \\
\hline Cola millenni & $34(51 \pm 3.7) 67$ & - & $50(61.4 \pm 2.8) 70$ & - & $10(12.8 \pm 1.0) 20$ & - & 34.5 & - \\
\hline Cola nitida & $39(55.9 \pm 2.9) 69$ & $9(23.4 \pm 3.2) 40$ & $50(61.4 \pm 2.8) 70$ & $60(64.5 \pm 1.4) 70$ & $15(22.1 \pm 1.3) 28$ & $22(26.5 \pm 0.9) 31$ & 21.8 & 2 \\
\hline Kleinhovia hospita & $4(10.2 \pm 1.0) 15$ & - & $35(48.2 \pm 3.7) 69$ & - & $7(10.3 \pm 0.8) 15$ & - & 23.4 & - \\
\hline Malanchata alnifolia & $22(28.3 \pm 1.0) 33$ & $20(34 \pm 2.9) 48$ & $48(57.3 \pm 2.3) 70$ & $50(60.8 \pm 2.4) 70$ & $10(21.5 \pm 1.8) 30$ & $10(17 \pm 2.3) 30$ & 14.6 & 29.8 \\
\hline Mansonia altissima & $18(24.3 \pm 1.3) 30$ & $47(53.3 \pm 1.5) 60$ & $30(47.2 \pm 3.5) 60$ & $50(60.8 \pm 1.6) 68$ & $10(20.5 \pm 2.2) 30$ & $20(25.6 \pm 1.4) 30$ & 20.5 & 23.8 \\
\hline Pterigota marcocarpa & $19(25.3 \pm 1.2) 29$ & - & $44(53.2 \pm 1.7) 61$ & - & $6(7.1 \pm 0.3) 9$ & - & 14.5 & - \\
\hline Thebroma cacao & $200(242.8 \pm 12.6) 320$ & $65(89.7 \pm 5.2) 120$ & $15(26 \pm 1.9) 35$ & $24(30.4 \pm 2.1) 44$ & $9(11.1 \pm 0.7) 15$ & $10(12 \pm 0.6) 15$ & 47.7 & 27.1 \\
\hline Triplochyton scleroxylon & - & $100(139 \pm 8.2) 180$ & $38(46.1 \pm 1.7) 52$ & - & $10(14.5 \pm 1.1) 20$ & - & 46.3 & - \\
\hline Waltheria indica & $20(24.5 \pm 1.1) 30$ & $2(6.4 \pm 0.8) 10$ & $40(54.3 \pm 2.8) 65$ & $50(61.4 \pm 2.0) 72$ & $10(19.8 \pm 2.1) 30$ & $10(14.6 \pm 1.7) 26$ & 23.7 & 29.8 \\
\hline
\end{tabular}

- denotes no stomata, S.I = Stomata Index 

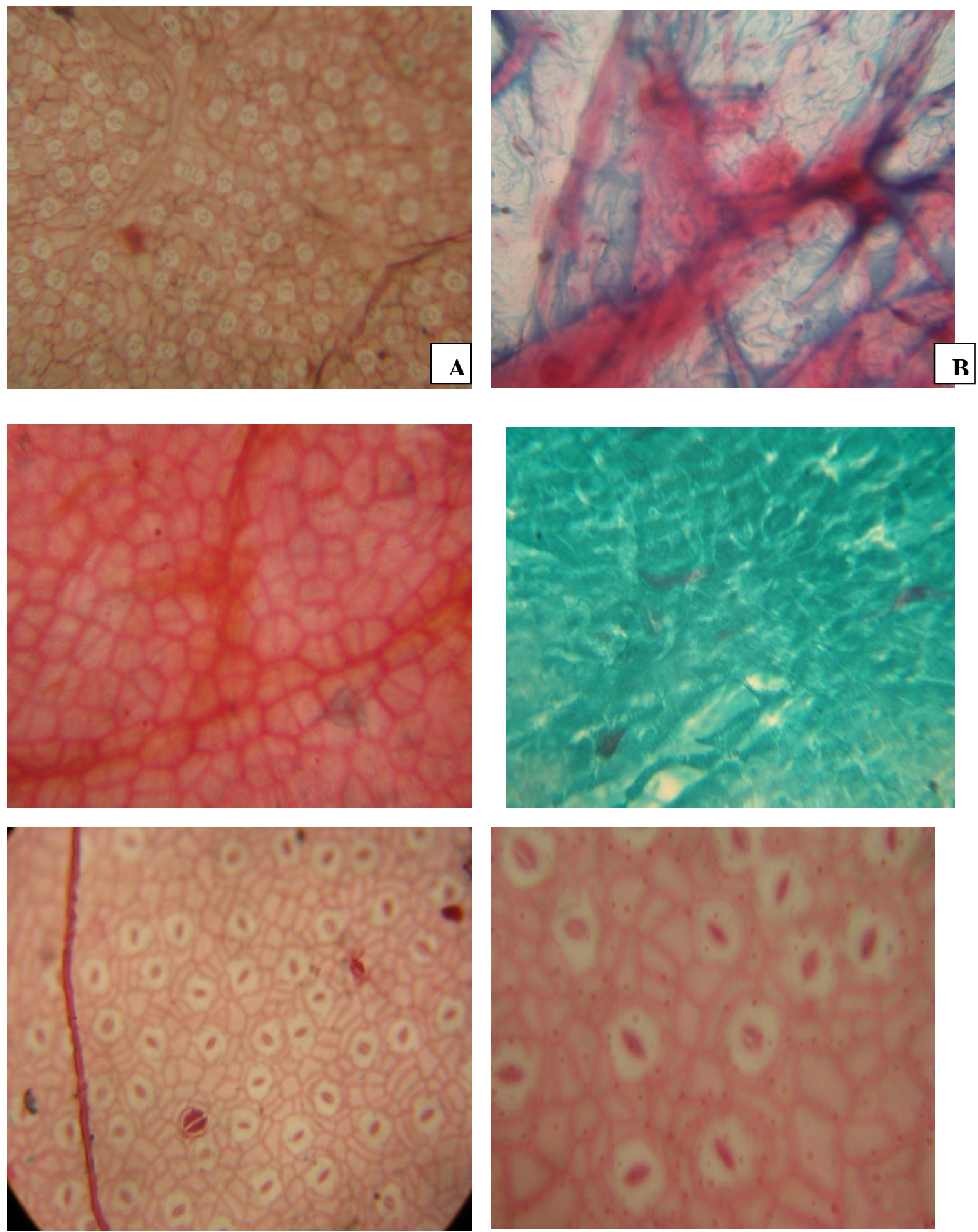

Fig. A, B: Abaxial and Adaxial surface of Theobroma cacao with anisocytic stomata.

Fig. C, D: Abaxial and Adaxial surface of Cola hispida with laterocytic and no stomata respectively. Fig E, F: Adaxial and Abaxial surface of Cola nitida with staurocytic stomata. 


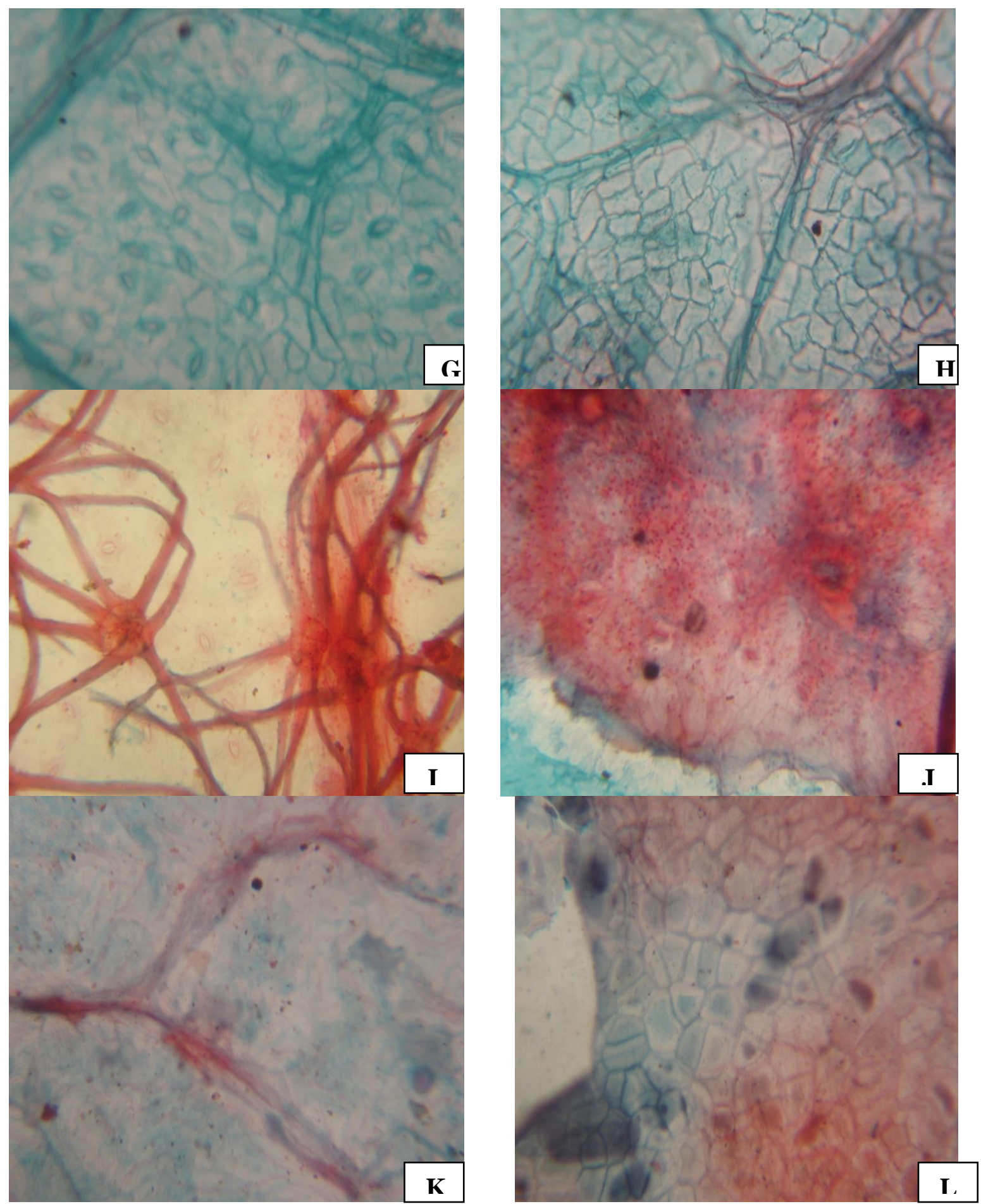

Fig. G, H: The Adaxial and Abaxial surface of Triplochyton scleroxylon with anomocytic and no stomata respectively.

Fig. I, J: Adaxial and Abaxial surface of Waltheria indica with paracytic and anisocytic stomta respectively. Fig. K, L: Adaxial and Abaxial surface of Kleinhovia hospita with no stomata and anisocytic type respectively. 


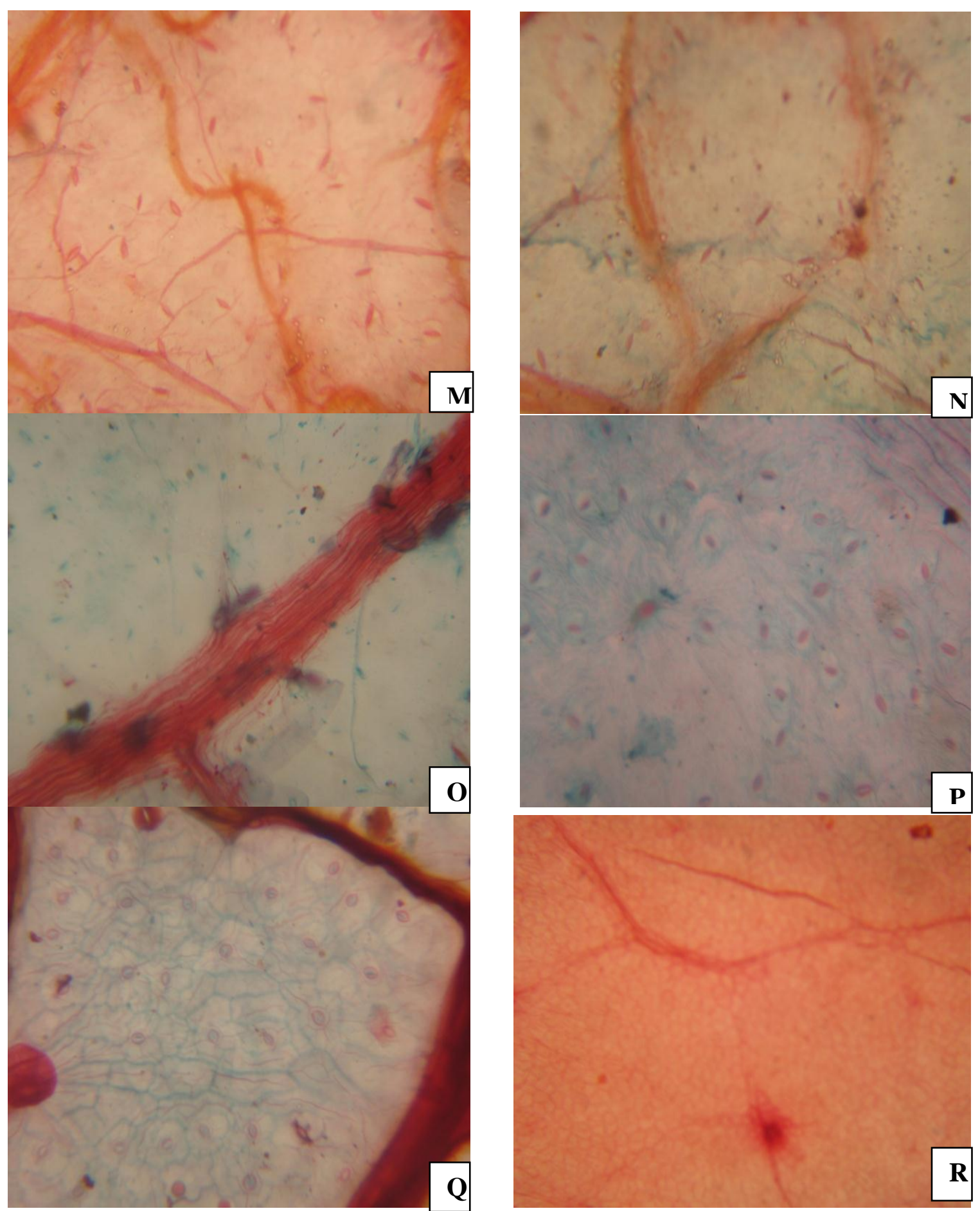

Fig. M, N: Adaxial and Abaxial surface of Malanchata alnifoia with paracytic stomata.

Fig. O, P: Adaxial and Abaxial surface of Mansonia altissima with paracytic stomata.

Fig. Q, R: Adaxial and Abaxial surface of Cola millenni with no stomata and anomocytic stomata. 

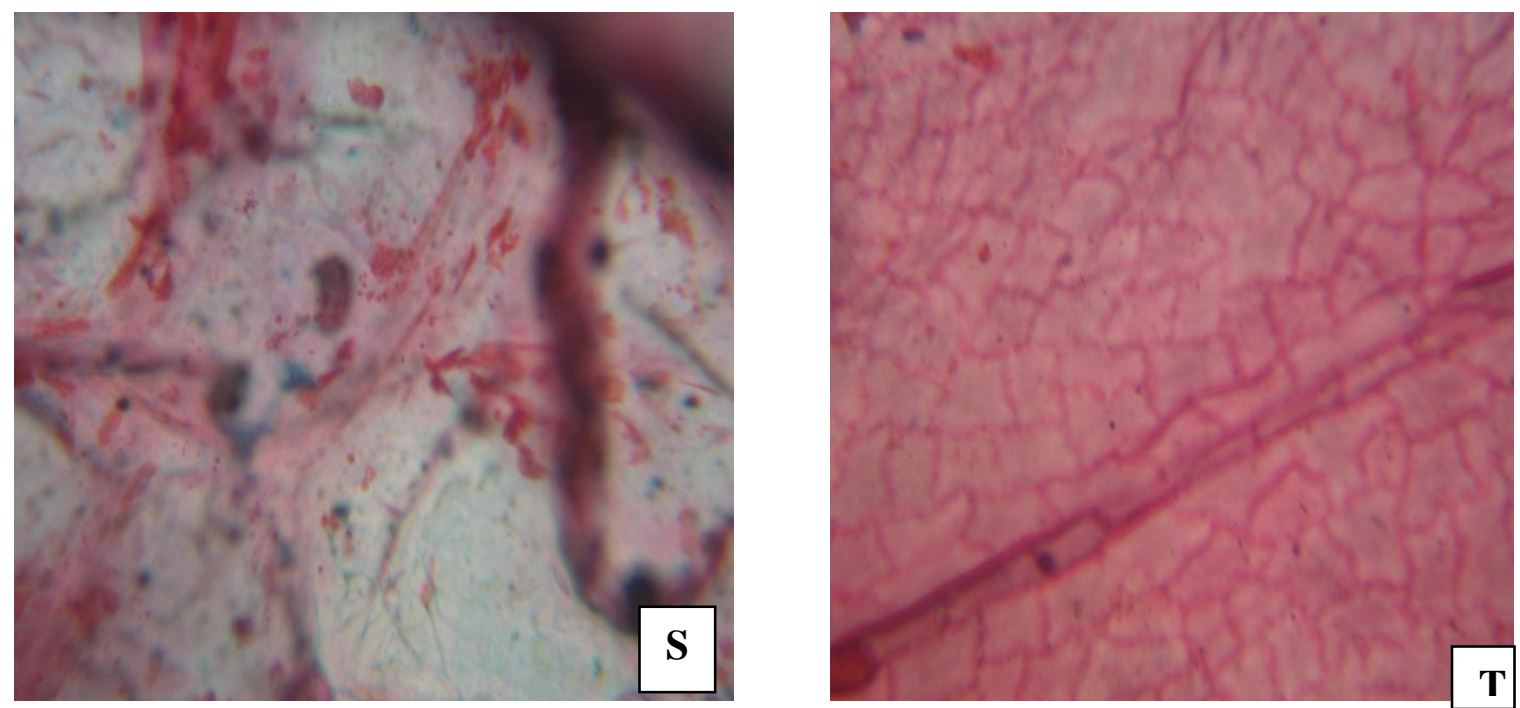

Plate S, T: Adaxial and Abaxial surface of Pterigota marcocarpa with no stomata and paracytic stomata type.

\section{DISCUSSION}

The study of the epidermal surfaces of Sterculiaceae revealed a number of important micromorphological characters and these characters exhibit interesting interspecific variations that are of diagnostic significance for identification and delimitation

The cell wall shape varied greatly among $T$. cacao, W. indica, C. nitida, C. millenni, T. scleroxylon and P. marcocarpa can be grouped together as they possessed polygonal shape on both the adaxial and abaxial surfaces. Curved and slightly straight walls were associated with irregular cell shape while straight walls were associated with polygonal cells. These findings were in agreement with Stace (1965) who suggested that environmental conditions such as humidity play a significant role in determining the pattern of anticlinal walls. There is a wide variation in the number and distribution of stomata found in all the species studied. Classification of different types of stomata complexes is based on the number and position of the subsidiary cells and the ontogeny of the cell types. In consonance with Metcalfe and Chalk (1979) the presence of both anisocytic and paracytic stomata in Waltheria indica distinguished

\section{REFERENCES}

Adegbite, A.E. (2008): Leaf anatomical studies in some species of the tribe Cichorieae (Asteraceae) in Nigeria. Comp. Newsl., 46: $49-58$.

Aworinde, D.O. and Ogundairo, B.O. (2009): Leaf epidermal micromorphology in some members of Solanum L. (Solanaceae) in Nigeria. University of Zambia Journal of Science and Technology, 13(2): $29-40$. it from other species and is diagnostic. The presence of laterocytic stomata found in Cola hispida also distinguished it from the remaining species. The appearance of more stomata on the abaxial surface is an adaptation to water loss (Mbagwu et al. 2008). Furthermore, this appears to be a coping strategy to survive drought (Aworinde and Ogundairo, 2009). Also, in agreement with Metcalfe and Chalk (1950) and Mbagwu and Edeoga (2006) who observed that stomata are usually more on the lower epidermis in species of Amaranthus and Vigna respectively. The differences in stomata density and stomata index of the species are often a reflection of physiological responses to combination of environmental factors which could be useful in delimitation at the species level (Adegbite, 2008). The striking difference observed in the data and figures of the characters such as stomata sizes, stomata index, stomata density and in the size, shape and density of the epidermal cells of the species studied are therefore of taxonomic importance. Also the similarities observed in the stomata type and epidermal cells arrangement of the species provides evidence for their genetic and evolutionary relationships and justification for their taxonomic grouping.

Burkill, H.M. (1985): The useful plants of west tropical Africa. $2^{\text {nd }}$ edition, Royal Botanical Garden, Kew, pp. 507 - 705.

Holmgren, P.K. and Keuken, W. (1974): Index Herbariorum. Part 1 . The herbaria of the world. Utrecht.

Hussin, K.H., Seng, H., Ibrahim, W.Q., Gen, L.J. Ping and Nian, L. (2000): Comparative leaf anatomy of A/pinia Roxb. species (Zingiberaceae) from China. Bot. J. Linn. Soc., 133: $161-180$. 
Isawunmi, M.A. (1989): Leaf epidermal studies in the genus Venonia Schreber tribe Vernoniaceae (Compositae) in West Africa. Feedes Repert. 100: 335 - 355.

Mbagwu, F.N and Edeoga, H.O. (2006): Observation on the vegetative and floral morphology of some Vigna species (Leguminosae-Papilionoideae), Pakistan Journal of Biological Sciences, 9: 1754 1758.

Mbagwu, F.N., Nwachukwu, C.U. and Okoro, O.O. (2008): Comparative leaf epidermal studies on S. marcocarpon and S. nigrum, Research Journal of Botany, 3(1): $45-48$.

Metcalfe, C.R. and Chalk,L.(1950). Anatomy of dicotyledons. Oxford: Clarendon press, pp $1067-1074$.
Metcalfe, C.R. and Chalk, L. (1979): Anatomy of dicotyledons. Oxford: Clarendon press, pp $456-473$

Motamayor, J. and Lanaud, C. (2002): Cacao domestication: The origin of the cacao cultivated by the Mayas. Heredity, 89: 380 $-386$.

Salisbury, E.J. (1927): On the causes and ecological significance of stomata frequency with special reference to the woodland flora. Phil. Trans. Roy. Soc., 21B: 1065.

Stace, C.A. (1965): Circular studies as aid to plant taxonomy. Brit. Mus. (Nat. Hist. Bull.) Bot., 4: $3-78$. 